\title{
CARBON STORAGE IN BEECH STANDS ON THE CHŘIBY UPLANDS
}

\author{
JIŘÍ SCHNEIDER ${ }^{1}$, KATEŘINA HOLUŠOVÁ², JAN RYCHTÁŘ³ ${ }^{3}$ ILJA VYSKOT ${ }^{1}$, IVANA \\ LAMPARTOVÁ ${ }^{1}$
}

${ }^{1}$ Department of Environmentalistic and Natural Resources, Faculty of Regional Development and International Studies, Mendel University in Brno, Tř. Generála Píky 2005/7, 61300 Brno, Czech Republic; e-mail: jiri.schneider@ mendelu.cz, ilja.vyskot@mendelu.cz, ivana.lampartova@mendelu.cz

${ }^{2}$ Forest Management Institute Brandýs n. Labem, branch Brno, Vrázova 1, 61600 Brno, Czech Republic; e-mail: katerina.holusova@mendelu.cz

${ }^{3}$ Faculty of Forestry and Wood Technology, Mendel University in Brno, Zemědělská 3, 61300 Brno, Czech Republic

\begin{abstract}
Schneider J., Holušová K., Rychtář J., Vyskot I., Lampartová I.: Carbon storage in beech stands on the Chřiby uplands. Ekológia (Bratislava), Vol. 34, No. 1, p. 26-38, 2015.

The submitted scientific statement is a contribution to solutions of monitoring the storage of carbon in the woods and its emissions. Four permanent research plots were established in the area of the Chriby uplands in the Czech Republic. The plots are made of forest stands with nearly $100 \%$ of European beech (Fagus sylvatica L.). The stands form simple spatial structures of about the same age (about 180 years). They represent, however, varying site conditions (dwarf acid beech stands, herb-rich beech stands and transitions between them). For quantification of carbon storage, standard dendrometric methods and the Field-Map technology were used. The total amount of carbon was established as the sum of further documented carbon storages in the aboveground biomass, the belowground biomass, woody debris and the forest soil. Determination of total amount of carbon was addressed in a version manner. In the first version, the estimate of the total amount of carbon was established based on Wutzler et al. (2008) equations for the aboveground biomass (AGB) and the belowground biomass (BB). In the second version, the AGB was calculated according to Joosten et al. (2004), the BB according to Wirth et al. (2003), the values of storages were consistent with Mund (2004) for woody debris, and with Macků in Kolektiv (2007) for forest soil. Total carbon storage per hectare of stand is in average $370.2 \mathrm{t}$. Obtained outcomes support the quantitative results of latest research related to carbon in the woods.
\end{abstract}

Key words: biomass, carbon storage, Fagus sylvatica L., forest stands, simplified structure, woody debris.

\section{Introduction}

In the forest ecosystem, carbon is present in various forms. Two basic forms are to be distinguished - carbon within the biomass of organisms and carbon contained within the soil (Lal, 2005). The carbon in the biomass means aboveground biomass and belowground biomass. Moreover, woody debris is added as the biomass of the vegetation (Tyrrell, Ross, 2009). Car- 
bon in the soil includes soil organic carbon (SOC) and soil inorganic carbon (SIOC). The litter is usually also taken into account, especially with respect to forest soil (Cienciala et al., 2006).

The share of carbon in woody vegetation is quantitatively assessed using the coefficient 0.5. Thus, the amount of carbon is often assessed by the amount of the biomass in the stand by means of transformational assessment. It has been proved however that young stands contain less carbon than the old ones (Tyrrel, Ross, 2009). Also a different tree species composition leads to different storage of carbon. For example, Joosten et al. (2004) state that the carbon storage in the biomass of a 120 -year-old beech stand is $160 \mathrm{t}$ of $\mathrm{C}$ per hectare, Jandl et al. (2007) found $100 \mathrm{t}$ of $\mathrm{C}$ per hectare in a 100-year-old spruce stand.

The carbon is ascertained by means of two principal approaches - measuring the carbon storage and measuring its flux.

By measuring the amount of carbon, we obtain what is called the carbon storage estimation. The measuring of the carbon flux is important to find out whether the stand in question is a source of carbon or whether it binds carbon. The following are used: indirect measurement - measuring of changes in carbon storage which can be used to infer the carbon fluxes at a specific level of reliability; direct measurement - the results of carbon fluxes in the stand show how much carbon (in the form of $\mathrm{CO}_{2}$ ) is issued (+) or bound (-) in a specific period (Zhang et al., 2009)

The stand storage and the area of the stand soil represent the fundamental data for the quantification of the changes in carbon storage contained within the biomass. The quantification of carbon balance uses two main alternative methods. The first method is the fundamental one based on the quantification of increments and losses in the specific area [the corresponding forest category $(i)$, climate zone $(j)$ and management methods $(k)$ ] according to the equation:

$$
\Delta \mathrm{C}=\sum_{\mathrm{ijk}}\left[A_{i j k} *\left(C_{I}-C_{L}\right)_{i j k}\right]
$$

where $A_{\mathrm{ijk}}$ is the forest area in ha; $C_{\mathrm{I}}$ is the storage increment and $C_{\mathrm{L}}$ is the loss of carbon storage.

The second approach is represented by the method of establishing the changes in the storage, where the change in carbon storage in the biomass is determined by the difference of the storage between two periods, i.e.:

$$
\Delta \mathrm{C}=\sum_{\mathrm{ijk}}\left(C_{t 2}-C_{t 1}\right) /\left(t_{2}-t_{1}\right)_{i j k}
$$

where $C_{\mathrm{t} 2}$ and $C_{\mathrm{t} 1}$ are the carbon storage amounts in a unit of a forest ecosystem at moments $t_{2}$ and $t_{1}$, respectively (IPPC, 2003).

Currently, there are several other methods for the carbon storage and flux estimation. (Zhang et al., 2009):

- forest inventory - biomass volume measuring,

- remote sensing (Earth observation) - relationship between the biomass and the surface cover,

- Eddy covariance - direct measurement of $\mathrm{CO}_{2}$ emissions (release and uptake),

- inverse methods - relationship among the biomass, the $\mathrm{CO}_{2}$ flow and the $\mathrm{CO}_{2}$ atmospheric movement. 
All these methods differ in terms of degree of their accuracy and resolution.

Carbon storage in the forest stand is the sum of values of the following five different storages (IPPC, 2003): aboveground biomass + belowground biomass + woody debris + litterfall + soil.

To establish the aboveground biomass two approaches are usually used subject to available data. They are the use of biomass conversion and expansion factors or biomass equations (Cienciala et al., 2006; Somogyi et al., 2007).

The first method is used, if we know the storage of timber from which the volume of the biomass can be derived. The biomass equations are preferred, if we have access to the actual values of trees (DBH, height) from the target population (Zhang et al., 2009).

The factors for biomass estimation are used in relation to the availability of the values of tree or trunk volumes at required outputs. Three basic types of factors are used (Somogyi et al., 2007): conversion factors (CF), biomass expansion factors (BEF), biomass conversion and expansion factors (BCEF).

In the simplest cases, the conversion factor $(\mathrm{CF})$ is used in relation to the value of wood density. If the estimation of total biomass is necessary, but only the data on the volume of timber is available, the expansion factor (BEF) or the combined factor (BCEF) are used.

Eddy covariance is a method based on searching for the covariance between the vertical component of wind velocity and the $\mathrm{CO}_{2}$ concentration in the air above the stand. The eddy covariance technique is used to measure the $\mathrm{CO}_{2}$ flux of water vapour, energy or other gases, e.g. methane, between the atmosphere and an ecosystem.

It is a highly accurate method. The $\mathrm{CO}_{2}$ flux is usually underestimated by less than $5 \%$ during the day and less than $12 \%$ during the night. On the other hand, it is limited in space - the conditions like homogenous canopy, stable environment conditions, especially terrain shape, and stationary currents hardly ever exceed the area of a hectare. Eddy covariance measurement is conducted at a number of places for over ten years (Zhang et al., 2009).

To establish the carbon content of root biomass is a difficult and time-demanding measuring in all forest ecosystems and the methods have not been generally standardised (Cairns et al., 1997). The procedure can be generalised in two basic steps. In the first step, the amount of the biomass contained within the roots is determined; in the second step the biomass is converted into carbon by means of conversion factors - carbon concentration in the biomass (Brown, 2002). The carbon concentration in roots is based on its relative proportion in the dry matter. Claus (2003) presents the carbon concentration of $0.404 \mathrm{~g} \mathrm{~g}^{-1}$ of the dry matter for the European beech. However, generally the carbon concentration is used in the value of $0.5 \mathrm{~g} \mathrm{~g}^{-1}$ of dry matter (Brown, 2002).

The most frequently used method for the establishment of the biomass located in roots is its inference from the amount of the aboveground biomass using the 'root:shoot ratio (R/S)' which expresses the ratio between the roots and the aboveground biomass (Cairns et al., 1997). $\mathrm{R} / \mathrm{S}$ values range between $0.18-0.30$.

The second applicable method to determine the biomass of roots, specifically of beech, is to use the biomass equation (BE). The amount of the biomass $(y)$ is dependent on the diameter at breast height $(D)$ with variation coefficients $\left(b_{0}, b_{1}\right)$. Wirth et al. (2003) presents the equation in a linear form: 


$$
y=\beta_{0}+\beta_{1}^{*} \ln D
$$

Probably the most objective robust equation for beech root amount establishment was created by Wutzler et al. (2008). $D$ in an exponential form:

$$
y=\beta_{0}^{*} D^{\beta 1}
$$

The carbon estimation is created analogically to the aboveground biomass - first the amount of the biomass is calculated, then the amount of the carbon in this biomass is expressed.

The amount of biomass in decomposing wood can be expressed by means of the following formula created by Mund (2004):

$$
w=v \times \mathrm{BWD}
$$

where $w$ is the biomass content $(\mathrm{kg}) ; v$ is the volume $\left(\mathrm{m}^{3}\right)$; BWD is the basic wood density $\left(\mathrm{kg} \mathrm{m}^{-3}\right)$; appropriate decay classes.

The total amount of woody debris per the explored unit will be gained by adding up the contents of the biomass of individual pieces (Joosten et al., 2004).

Measurement of the soil carbon is partial. In the soil there is soil organic carbon (SOC) and soil inorganic carbon (SIOC) (Lal, 2005).

The SOC in the soil and in the forest ecosystem as a whole creates a cycle of its origination, deposition and release. The SIOC is also a considerable component of soil (Adams, Post, 1999).

It is not taken into account for the purpose of establishing the total amount of carbon in the soil in relation to possible sequestration or release. Its amount is determined on the basis of the amount of carbonates in the soil.

Organic horizons of forest soils - LFH horizons - are defined as dead biomass according to IPPC (2003). In the conditions of the Czech Republic, they are classified as a component of forest soil and the methodology of carbon content determination for the litter horizon is the same as when determining its content in mineral horizons (Cienciala et al., 2006).

The concentration of $C_{\text {ox }}$ in forest soils ranges between $0 \%$ for very young soils and up to $50 \%$ for some histosol or gley soils (Lal, 2005).

The content of soil organic mass (SOM) in the soil is highly variable. The surface layers of most mineral soils contain approximately several mass percents of organic substances. The usual formulation of the soil organic mass calculation is (Šimek, 2003):

$$
\mathrm{SOM}=\mathrm{C}_{O X}{ }^{*} 1.72
$$

where $C_{\text {ox }}$ is the carbon concentration value; 1.72 is the empirical coefficient expressing the average content of $C$ in soil organic mass, where the considered value is $58 \%$ of mass.

\section{Material and methods}

In 2008, four comparative research plots were singled out in the area Chriby for the purpose of the carbon study. The ridges of the Chriby are covered in developed Cambisol both saturated and non-saturated, the slopes are covered 
with brown soil on loess loam. The territory is located in mild warm area with average temperatures ranging from 7.6 to $8.2^{\circ} \mathrm{C}$ and annual precipitation around $650 \mathrm{~mm}$. The territory of the Chřiby is forested nearly in its entire area.

Three of the research plots are 1 ha in area and one of them is 0.5 ha (limited by site conditions). There are beech stands of approximately the same age (180 years) with a simplified structure varying by site. The plots are contained within forest small-scale specially protected areas, supraregional biocentre USES Buchlovské lesy and European significant location of NATURA 2000 Chriby. According to the valid forest management plan, the studied stands are characterised by the following data:

- The Máchova dolina research plot (0.5 ha) is a component of the Máchova dolina Natural Monument in stand no. 402Ea17. The stand area is 2.51 ha. Further information: forest type group 3K6, tree species composition beech $100 \%$, age - 187 years, stocking - 8, rotation period - 150 years. Soil type is Cambisol, typical oligotrophic.

- The Sever research plot (1 ha) is located in the northern part of the Holý kopec Nature Reserve, stand no. 203Ea17. The stand area is 34.7 ha. forest type group $4 \mathrm{D}$ - enriched beech stand, tree species composition - beech $100 \%$, age - 162 years, rotation period - 150 years, stocking - 8. Soil type is Cambisol luvic (gley).

- $\quad$ The Rynek research plot (1 ha) is located in the southern part of the Holý kopec Nature Reserve, stand no. 204Ea17. The stand area is 26.00 ha. Further information: forest type group 3B - rich oak beech stand, tree species composition - beech $100 \%$, age - 164 years, stocking - 8, rotation period - 150 let. Soil type is Cambisol, typical mesotrophic.

- The Ocásek research plot (1 ha) is found in the proposed Ocásek Natural Monument, stand no. 57 Ba17/1. The area of the stand group is 3.27 ha. Further information: forest type group 3A - lime and oak beech stand, tree species composition - beech 99\%, lime $1 \%$ and admixture of elm. Further information: age - 183/4 (age of regeneration in the young growth); stocking - 7/3 (young growth), rotation period - 140 years. Soil type is Cambisol, ranker (Schneider et al., 2008).

The basis for the concerned biometric measurements is the methodology presented in Developmental Dynamics of Virgin Forest Reserves in the Czech Republic (Vrška et al., 2002). The Field-Map technology was used to trace out the positions of all standing living trees. All trees with $10 \mathrm{~cm}$ diameter in breast height with bark were measured and described. Concerning dendrometric characteristics, the diameter at breast height (DBH) was taken at the height of $1.3 \mathrm{~m}$ from the trunk foot. Another explored characteristic was the height of each tree. The tree height was measured with $0.5 \mathrm{~m}$ accuracy by an ultrasound altimeter. These input data were used to establish the volume of trunks of timber.

Woody debris includes all dead biomass standing or lying on the soil surface, excluding litterfall. Woody debris shall thus consist of fallen trunks, dead trees, stumps, wind breakages. The tracing out of their positions was also conducted by means of the Field-Map. The limit of the diameter for registering was $10 \mathrm{~cm}$. As for lying wood, the entire trunk even with the part which may exceed the limits of the area is taken into account. The diameter is measured with $1 \mathrm{~cm}$ accuracy at both ends of the trunk. The length of the trunk is determined by the Field-Map application in relation to the location. This application (Field-Map Data Collector) directly calculates the volume of the lying wood as well. For further calculations concerning the woody debris, it was necessary to define the decay class. Three decay classes were determined:

1. hard: we can identify the tree species without any difficulties, usually there is bark and healthy hard wood;

2. decomposing wood is not compact in its entire length, the tree species can usually be still identified;

3. disintegrated wood at a well developed stage of decay, tree species is not $100 \%$ certain, the trunk can be kicked through.

The total volume of biomass in individual components was specified, based on biometric surveys, in order to establish the share of carbon - aboveground biomass, belowground biomass and forest soils.

First, the amount of the aboveground biomass was established. Several different methods based on the procedures referred to above were used. Table 1 lists the useful equations for the calculation of the aboveground biomass of European beech Fagus sylvatica L.

$\mathrm{T}$ a b l e 1. Equations for the calculation of the aboveground biomass (B) of Fagus sylvatica in dependence on the diameter at breast height $(\mathrm{D})$ and the tree height $(\mathrm{H})$.

\begin{tabular}{|l|l|c|c|c|}
\hline Source & Formula & $\boldsymbol{\beta}_{0}$ & $\boldsymbol{\beta}_{1}$ & $\boldsymbol{\beta}_{2}$ \\
\hline Muukkonen (2007) & $B=\beta_{0} D^{\beta 1}$ & 0.240 & 2.322 & \\
\hline Cienciala (2005) & $B=\beta_{0} D^{\beta 1} H^{\beta 2}$ & 0.047 & 2.121 & 0.697 \\
\hline Wutzler (2007) & $B=\beta_{0} D^{\beta 1} H^{\beta 2}$ & 0.0551 & 2.11 & 0.589 \\
\hline
\end{tabular}


The equation presented in Joosten et al. (2004) was used to calculate the amount of carbon in the aboveground biomass (Table 2).

$\mathrm{T}$ a b l e 2. Equation for the calculation of carbon content in the aboveground biomass (B) in dependence on the diameter at breast height (D) and the tree height (H) for Fagus sylvatica according to Joosten et al. (2004).

\begin{tabular}{|l|l|c|c|c|}
\hline Source & Formula & $\boldsymbol{\beta}_{\mathbf{0}}$ & $\boldsymbol{\beta}_{\mathbf{1}}$ & $\boldsymbol{\beta}_{\mathbf{2}}$ \\
\hline Joosten $(2004)$ & $\ln B=\beta_{0}+\beta_{1} \ln \mathrm{D}+\beta_{2} \ln \mathrm{H}$ & -3.7378 & 2.1596 & 0.6338 \\
\hline
\end{tabular}

Comparatively, the estimation of aboveground biomass was carried out by means of BCEF (Kolektiv 2007) (Table 3).

T a b l e 3. Biomass conversion and expansion factor (BCEF) for the European beech (Kolektiv, 2007).

\begin{tabular}{|l|l|c|c|c|}
\hline Source & Formula & $\mathbf{p}_{\mathbf{1}}$ & $\mathbf{p}_{\mathbf{2}}$ & $\mathbf{P}_{\mathbf{3}}$ \\
\hline CzechCarbo (2007) & $C B E F=p_{1}{ }^{*} p_{2}{ }^{*} e^{-A / p 3}$ & 0.558 & 0.246 & 100 \\
\hline
\end{tabular}

The amount of the biomass is the result of multiplication of the volume of timber (V) and BCEF factor (Somogyi et al., 2007):

$$
\mathrm{B}=\mathrm{V} * \mathrm{BCEF}
$$

To convert the biomass into the carbon amount, the coefficient of 0.5 was used (Joosten et al., 2004; Mund, 2004). To calculate the belowground biomass, two equations based on Wirth et al. (2003) (Table 4).

To convert the carbon amount in the belowground biomass, we used the value of 0.5 in accordance with Brown (2002).

$\mathrm{T}$ a b l e 4. Equations for the calculation of the belowground biomass ( $\mathrm{y}$ ) in dependence on the diameter at breast height (D) of Fagus sylvatica.

\begin{tabular}{|l|l|c|c|}
\hline Source & Formula & $\boldsymbol{\beta}_{\mathbf{0}}$ & $\boldsymbol{\beta}_{1}$ \\
\hline Wirth (2003) & $y=\beta_{0}+\beta_{1} \ln \mathrm{D}$ & -3.88751 & 2.51218 \\
\hline Wutzler (2007) & $y=\beta_{0}{ }^{\star} D^{\beta 1}$ & 0.0292 & 1.70 \\
\hline
\end{tabular}

The carbon content in the soil was generated on the basis of Macků in Kolektiv (2007) where the carbon content in the forest soil (including organic and mineral horizons) was established in dependence on the forest altitudinal vegetation zone and the ecological trofic and edafic classification. Within the various comparative plots the values of the carbon in the aboveground biomass according to various authors were compared by means of statistical methods (Drápela, 2000). To compare the statistically significant differences of the calculated values among the authors, the single-factor dispersion analysis ANOVA and Scheffés method of multiple comparison (at the level of significance $p=0.05$, i.e. at $95 \%$ probability) were used.

\section{Results}

When assessing the volume of aboveground biomass the highest number of trees was found in the Máchova dolina PRP - 296 specimens; the lowest number of trees was found in the Rynek PRP. In the total sum for individual PRP, the highest storage is in the Sever PRP $1000.11 \mathrm{~m}^{3}$; the lowest storage is even after the conversion in the Máchova dolina PRP $305.18 \mathrm{~m}^{3}$ (Table 5).

In terms of the woody debris the most standing and lying trunks are found in the Rynek PRP - 34 pieces, the fewest are in the Máchova dolina PRP - 10 pieces. For each piece, the de- 
gree of decay and the volume were calculated on the basis of the trunk length and diameter. The highest amount of woody debris is in the Rynek PRP $-72 \mathrm{~m}^{3}$, the lowest in the Máchova dolina PRP $-7.04 \mathrm{~m}^{3}$. The total number of trunks and the storage of individual plots are presented in Table 6.

T a b l e 5. Number of trunks and total storage.

\begin{tabular}{|l|c|c|}
\hline Permanent research plot & Number of trees (pieces) & Total storage $\left(\mathbf{m}^{\mathbf{3}}\right)$ \\
\hline Rynek & 125 & 795.76 \\
\hline Sever & 235 & 1000.11 \\
\hline Máchova dolina & 296 & 305.18 \\
\hline Ocásek & 128 & 798.98 \\
\hline
\end{tabular}

T a b le 6. The total number of pieces of woody debris and their volume.

\begin{tabular}{|l|c|c|c|c|c|c|}
\hline \multirow{2}{*}{$\begin{array}{l}\text { Permanent } \\
\text { research plot }\end{array}$} & \multicolumn{2}{|c|}{ Lying wood } & \multicolumn{2}{c|}{ Standing wood } & \multicolumn{2}{c|}{ Total } \\
\cline { 2 - 7 } & $\begin{array}{c}\text { volume } \\
\left(\mathbf{m}^{\mathbf{3}}\right)\end{array}$ & $\begin{array}{c}\text { Number } \\
(\mathbf{p i e c e s})\end{array}$ & $\begin{array}{c}\text { volume } \\
\left(\mathbf{m}^{3}\right)\end{array}$ & $\begin{array}{c}\text { Number } \\
(\mathbf{p i e c e s})\end{array}$ & $\begin{array}{c}\text { volume } \\
\left(\mathbf{m}^{3}\right)\end{array}$ & $\begin{array}{c}\text { Number } \\
(\mathbf{p i e c e s})\end{array}$ \\
\hline Rynek & 65.58 & 27 & 6.46 & 7 & 72.04 & 34 \\
\hline Sever & 30.77 & 15 & 10.53 & 7 & 41.30 & 22 \\
\hline Máchova dolina & 0.16 & 2 & 6.88 & 4 & 7.04 & 10 \\
\hline Ocásek & 33.17 & 14 & 16.05 & 10 & 49.22 & 24 \\
\hline
\end{tabular}

The amount of carbon was established as the sum of the carbon storage in the aboveground biomass, the belowground biomass, woody debris and the forest soil (including litter and mineral horizons).

\section{Carbon in the aboveground biomass}

The sums show the differing estimations of the amount in dependence on the used procedures. The highest values were achieved for the Sever PRP; the Rynek PRP and the Ocásek PRP are of approximately the same amount of carbon; the Máchova dolina PRP has the lowest amount (even when converted to $1 \mathrm{ha}$ ). The carbon amounts in the AGB related to the individual methods are best shown in Table 7. Figure 1 shows the optical comparison of the amounts.

\section{Carbon in the belowground biomass}

The results show that the largest storage in the BB is in the Sever PRP, the smallest in the Máchova dolina PRP. In comparison with the amount in the AGB in the other plots, the difference is not significant. In the Máchova dolina PRP we can see a high dependence of the $\mathrm{BB}$ amount on the number of trees per an area unit. Table 8 and Figure 2 show the carbon content estimations for the PRP according to the equations used. Statistically, both values are significant; therefore, they were taken account of in the consequent calculations of the total carbon content. 
$\mathrm{T}$ a b l e 7. Carbon storage in the aboveground biomass.

\begin{tabular}{|l|c|c|c|c|c|}
\hline \multirow{2}{*}{$\begin{array}{l}\text { Permanent } \\
\text { research plot }\end{array}$} & \multicolumn{5}{|c|}{ C storage in AGB $\left(\mathbf{t ~ h a} \mathbf{~}^{-1}\right)$} \\
\cline { 2 - 6 } & MUUKKONEN & CIENCIALA & WUTZLER & JOOSTEN & CBEF \\
\hline Rynek & 232.22 & 243.12 & 183.86 & 230.61 & 252.94 \\
\hline Sever & 266.40 & 298.95 & 225.98 & 280.40 & 318.38 \\
\hline Máchova dolina & 171.88 & 118.59 & 97.46 & 115.58 & 95.75 \\
\hline Ocásek & 250.76 & 250.24 & 190.50 & 238.48 & 250.66 \\
\hline
\end{tabular}

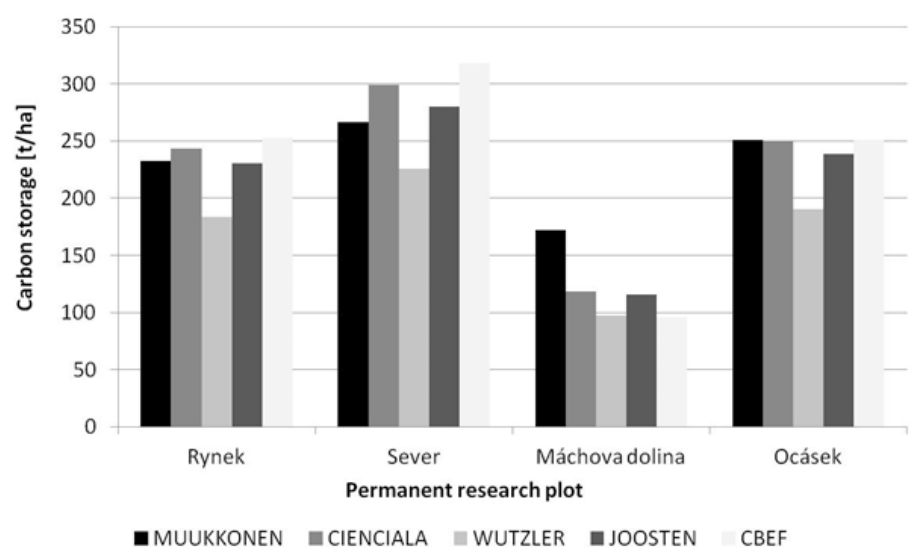

Fig. 1. Carbon storage in the aboveground biomass.

$\mathrm{T}$ a b l e 8. Carbon storage in the belowground biomass.

\begin{tabular}{|l|c|c|}
\hline \multirow{2}{*}{ Permanent research plot } & \multicolumn{2}{|c|}{ C storage in BB $\left(\mathbf{t ~ h a}^{-1}\right)$} \\
\cline { 2 - 3 } & WUTZLER & WIRTH \\
\hline Rynek & 36.40 & 44.44 \\
\hline Sever & 41.08 & 48.68 \\
\hline Máchova dolina & 26.06 & 29.97 \\
\hline Ocásek & 36.40 & 48.16 \\
\hline
\end{tabular}

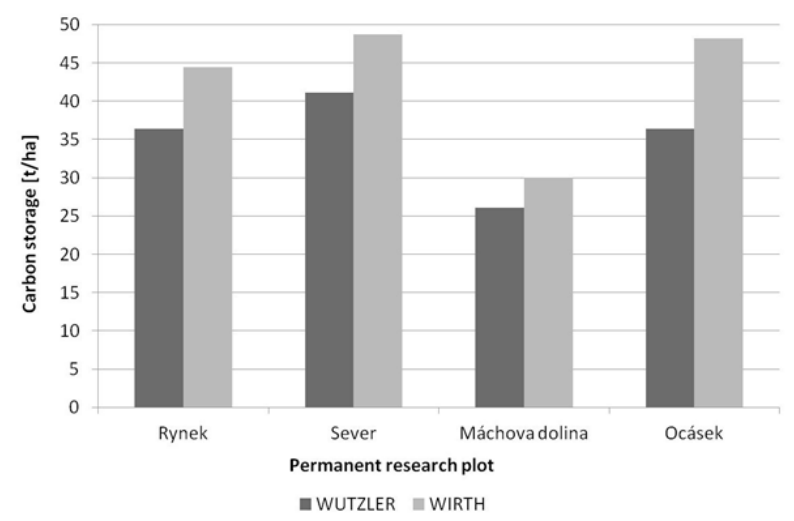

Fig. 2. Carbon storage in the belowground biomass. 


\section{Carbon in woody debris}

The highest total carbon storage was found in the Rynek PRP $\left(12.73 \mathrm{t} \mathrm{ha}^{-1}\right)$. The lowest storage was again found in the Máchova dolina PRP $\left(1.15 \mathrm{t} \mathrm{ha}^{-1}\right)$. The largest storage of standing wood is in the Ocásek PRP. The total values of particular plots are presented in Table 9.

T a b l e 9. Carbon storage in woody debris.

\begin{tabular}{|l|c|c|c|c|c|}
\hline \multirow{2}{*}{$\begin{array}{l}\text { Permanent } \\
\text { research plot }\end{array}$} & \multicolumn{2}{|c|}{ Lying wood } & \multicolumn{2}{c|}{ Standing wood } & \multirow{2}{*}{ Total carbon $\left(\mathbf{t ~ h a}^{-1}\right)$} \\
\cline { 2 - 5 } & Volume $\left(\mathbf{m}^{\mathbf{3}}\right)$ & Carbon $(\mathbf{t})$ & Volume $\left(\mathbf{m}^{\mathbf{3}}\right)$ & Carbon $(\mathbf{t})$ & \\
\hline Sever & 30.77 & 6.07 & 10.53 & 1.92 & 8.00 \\
\hline Rynek & 65.58 & 11.29 & 6.46 & 1.18 & 12.47 \\
\hline Ocásek & 33.17 & 8.34 & 16.05 & 3.39 & 11.73 \\
\hline Máchova dolina & 0.16 & 0.03 & 6.88 & 1.12 & 1.15 \\
\hline
\end{tabular}

\section{Carbon in the soil}

The highest value of $65.2 \mathrm{tha}^{-1}$ has been found for the Sever PRP, the lowest for the Ocásek PRP (Fig. 3).

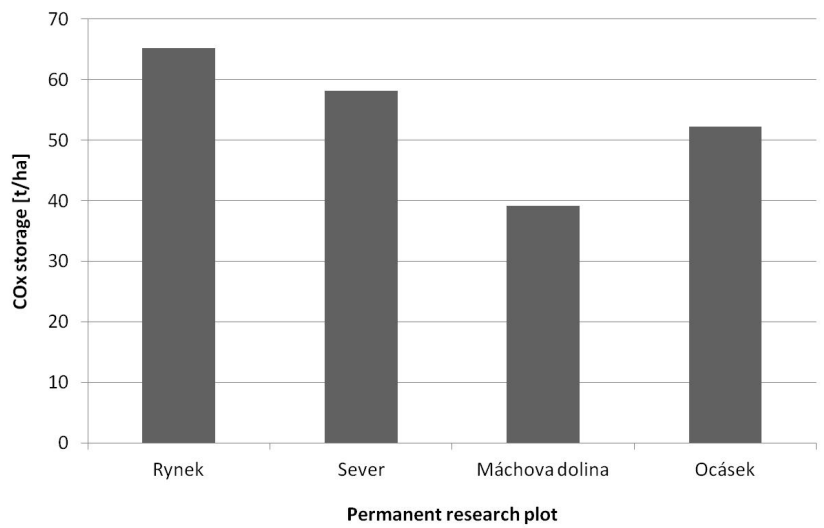

Fig. 3. Carbon storage in the forest soil.

\section{Total content of carbon}

The total carbon storages in the particular PRPs was calculated as the sum of the carbon in the AGB, the BB, woody debris and the forest soil. In the second one, the AGB was calculated according to Joosten et al. (2004). Table 10a shows the results of the total amount of carbon in tonnes per hectare calculated according to methodical version 1 for individual PRPs; Table $10 \mathrm{~b}$ shows the total amount of carbon in tonnes per hectare as calculated according to version 2. Figure 4 presents the total storage of carbon in tonnes per hectare calculated according to version 1; Figure 5 shows the total storage of carbon in tonnes per hectare calculated according to version 2 . 
T a b l e 10a. Total carbon storage per a hectare according to Wutzler et al. (2008) - version 1.

\begin{tabular}{|l|c|c|c|c|c|}
\hline $\begin{array}{l}\text { Permanent } \\
\text { research plot }\end{array}$ & $\begin{array}{c}\text { C storage in } \\
\text { AGB }\left(\mathbf{t} \mathbf{~ h a}^{-1}\right)\end{array}$ & $\begin{array}{c}\text { C storage in } \\
\mathbf{B B}\left(\mathbf{t ~ h a}^{-1}\right)\end{array}$ & $\begin{array}{c}\text { C storage in } \\
\text { soil }\left(\mathbf{t} \mathbf{~ h a}^{-1}\right)\end{array}$ & $\begin{array}{c}\text { C storage in } \\
\text { woody debris } \\
\left(\mathbf{t} \mathbf{~ h a}^{-\mathbf{1}}\right)\end{array}$ & $\begin{array}{c}\text { Total carbon } \\
\mathbf{s t o r a g e}\left(\mathbf{t} \mathbf{h a}^{-1}\right)\end{array}$ \\
\hline Rynek & 183.86 & 36.40 & 65.2 & 12.47 & 297.93 \\
\hline Sever & 225.98 & 41.08 & 58.17 & 8.00 & 333.22 \\
\hline Máchova dolina & 97.46 & 26.06 & 39.18 & 1.15 & 163.85 \\
\hline Ocásek & 190.50 & 36.40 & 52.24 & 11.73 & 290.87 \\
\hline
\end{tabular}

T a b l e 10b. Total carbon storage per a hectare according to Joosten et al. (2004) - version 2.

\begin{tabular}{|c|c|c|c|c|c|}
\hline $\begin{array}{l}\text { Permanent } \\
\text { research plot }\end{array}$ & $\begin{array}{l}\text { C storage in } \\
\text { AGB }\left(\mathrm{t} \mathrm{ha}^{-1}\right)\end{array}$ & $\begin{array}{c}\text { C storage in } \\
\text { BB }\left(\mathbf{t h a}^{-1}\right)\end{array}$ & $\begin{array}{c}\text { C storage in } \\
\text { soil Cox } \\
\left(\mathrm{t} \mathrm{ha}^{-1}\right)\end{array}$ & $\begin{array}{c}\text { C storage in } \\
\text { woody debris } \\
\left(\mathrm{t} \mathrm{ha}^{-1}\right)\end{array}$ & $\begin{array}{c}\text { Total carbon } \\
\text { storage }\left(\mathrm{t} \mathrm{ha}^{-1}\right)\end{array}$ \\
\hline Rynek & 230.61 & 44.44 & 65.2 & 12.47 & 352.72 \\
\hline Sever & 280.40 & 48.68 & 58.17 & 8.00 & 395.25 \\
\hline Máchova dolina & 115.58 & 29.97 & 39.18 & 1.15 & 185.87 \\
\hline Ocásek & 238.48 & 48.16 & 52.24 & 11.73 & 350.60 \\
\hline
\end{tabular}

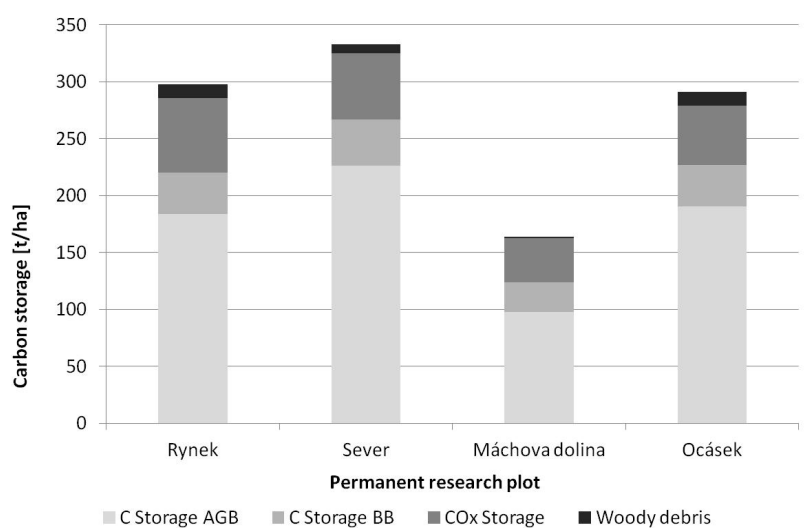

Fig. 4. Total carbon storage per a hectare according to Wutzler et al. (2008).

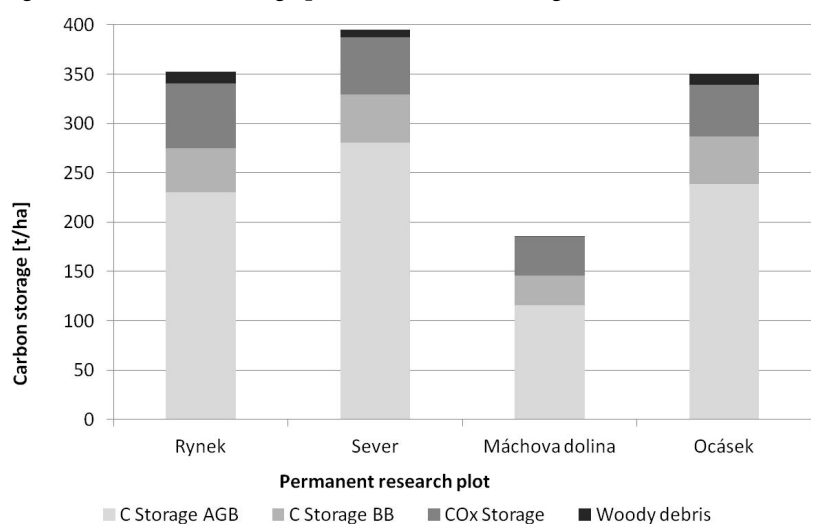

Fig. 5 Total carbon storage in research plots according to Joosten et al. (2004). 


\section{Total carbon storage of stands}

The storage of the stands was calculated on the basis of the data obtained through the results of individual PRPs. The hectare storage was multiplied by the area of the stand groups. The resulting values are presented in Table 11.

$\mathrm{T}$ a b l e 11. Total carbon storage in the stands.

\begin{tabular}{|l|l|c|c|c|}
\hline Stand group & $\begin{array}{l}\text { Permanent } \\
\text { research plot }\end{array}$ & $\begin{array}{c}\text { Total carbon } \\
\left(\mathbf{t ~ h a}^{-\mathbf{1}}\right)\end{array}$ & Stand area (ha) & $\begin{array}{c}\text { Total carbon } \\
\text { in the stand (t) }\end{array}$ \\
\hline $204 \mathrm{Ea} 17$ & Rynek & 348.25 & 26.00 & 9054.37 \\
\hline $203 \mathrm{Ea} 17$ & Sever & 399.72 & 34.70 & 13870.26 \\
\hline $402 \mathrm{Ea} 17$ & Máchova dolina & 196.45 & 2.51 & 493.09 \\
\hline $57 \mathrm{Ba} 17 / 1$ & Ocásek & 340.03 & 3.27 & 1111.89 \\
\hline
\end{tabular}

\section{Discussion}

Very few scientific papers deal with the establishment of carbon content in beech stands. In the Czech Republic, a study of allometric relationships and the establishment of conversion and expansion factors for Fagus sylvatica carbon content has only been conducted by Cienciala within the CzechCarbo project (Kolektiv, 2007). Scientific studies are conditioned by a natural occurrence of the European beech. The most available research studies come from Germany. Exceptionally, there are some in France, Switzerland, and Belgium. If we take into account another criterion - the age of the stand - only one piece of work remains for comparison - this is Mund (2004), in which the author compares the total carbon content in stands in dependence on different ways of management or no management - a regime without interference. Only in her study the stands are of a similar age and left without interference similar to the permanent research plots explored within our study. The age is a limiting classifier significant for the calculation of biomass amount by means of BCEF. The value of the age is not important when biometric equations are applied. The age of stand is used in forests grown on the basis of age classes; selection forests and modern methods for the exploration of forest conditions by means of statistical operational inventory do not use any time series.

Although all the four PRPs are beech stands of simplified structure, there are quite considerable differences among them concerning the carbon storage. The Máchova dolina PRP has the lowest value $-185.87 \mathrm{C} \mathrm{tha}^{-1}$. The forest soil, which contains $38.18 \mathrm{C} \mathrm{tha}^{-1}$, obviously affects the other carbon storages places; there is $115.58 \mathrm{Ct} \mathrm{ha}^{-1}$ in the $\mathrm{AGB}, 29.97 \mathrm{Ct} \mathrm{ha}^{-1}$ in the $\mathrm{BB}$, and only $1.15 \mathrm{C} \mathrm{tha} \mathrm{h}^{-1}$ in the woody debris.

The other extreme is the Sever PRP. In total, there is $395.25 \mathrm{C} \mathrm{tha}{ }^{-1}$. The AGB accumulates $280.40 \mathrm{C} \mathrm{t} \mathrm{ha}{ }^{-1}$, in comparison with others it contains $48.68 \mathrm{C} \mathrm{t} \mathrm{ha}^{-1}$ in roots. The SOC storage is $58.17 \mathrm{C} \mathrm{tha} \mathrm{h}^{-1}$.

The Rynek PRP and the Ocásek PRP are highly similar to each other. The total storage of carbon is $352.72 \mathrm{C} \mathrm{tha}^{-1}$ and $350.60 \mathrm{C} \mathrm{tha}^{-1}$, respectively. It means the difference is 'only' $1.12 \mathrm{C} \mathrm{tha}^{-1}$. The storage is different in different places of storage: the Rynek PRP has a higher amount of carbon in the soil and the woody debris. 
The total average carbon storage per hectare presented by Mund (2004) for beech stands is $352.5 \mathrm{C} \mathrm{tha}$.

\section{Conclusion}

The aim of the research was to quantify and evaluate the total carbon storage in the selected beech stands on explicated research plots. Based on the selected methodologies and terrain survey, living trees with the total storage of $2747 \mathrm{~m}^{3}$ was measured. The number of pieces of woody debris was 85 and the total volume was $202.5 \mathrm{~m}^{3}$.

The survey shows that even though all four plots were beech stands with a simplified structure, there were differences among them concerning the total carbon storage. The highest $\mathrm{C}$ storage was found in the Sever plot. In total this plot retains $395.25 \mathrm{C} \mathrm{tha} \mathrm{t}^{-1}$ : its aboveground biomass accumulates $280.40 \mathrm{C} \mathrm{t} \mathrm{ha}^{-1}$; the belowground biomass has $48.68 \mathrm{C} \mathrm{tha-1}$, and its woody debris retains $8 \mathrm{Ct} \mathrm{ha} \mathrm{t}^{-1}$. The storage of soil carbon is $58.17 \mathrm{C} \mathrm{tha-1}$.

The Rynek and Ocásek stands resemble to a great degree. The total carbon storage in the Rynek PRP is 352.72 C t ha $\mathrm{C}^{-1}: 230.61 \mathrm{C} \mathrm{t} \mathrm{ha}^{-1}$ in the aboveground biomass, $44.44 \mathrm{C} \mathrm{tha}^{-1}$ in the belowground biomass, $12.47 \mathrm{C} \mathrm{tha}^{-1}$ in the woody debris. The storage of soil carbon is 65.2 $\mathrm{C} \mathrm{tha} \mathrm{h}^{-1}$.

The total carbon storage in the Ocásek PRP is $350.60 \mathrm{C} \mathrm{t} \mathrm{ha}^{-1}: 238.48 \mathrm{C} \mathrm{tha}^{-1}$ in the aboveground biomass, $48.16 \mathrm{C} \mathrm{tha}^{-1}$ in the belowground biomass, $11.73 \mathrm{C} \mathrm{t} \mathrm{ha}^{-1}$ in the woody debris. The storage of soil carbon is $52.24 \mathrm{C} \mathrm{tha}^{-1}$. It means the difference is 'only' $1.12 \mathrm{C} \mathrm{tha-1}$. The storage is different in different places of storage (AGB, BB, soil, debris).

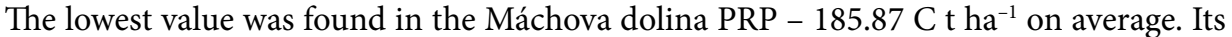
aboveground biomass sequesters $115.58 \mathrm{Ct} \mathrm{ha}^{-1}$, the belowground biomass $29.97 \mathrm{Ct} \mathrm{ha}^{-1}$, the woody debris only $1.15 \mathrm{C} \mathrm{t} \mathrm{ha}^{-1}$. The forest soil contains $38.18 \mathrm{C} \mathrm{tha} \mathrm{ha}^{-1}$.

Based on the confrontation of the results with the values presented in other studies, we can conclude that the estimation of the total carbon storage in the individual plots by means of combining the calculations of carbon storage in the aboveground biomass according to Joosten et al. (2004), the belowground biomass according to Wirth et al. (2003), woody debris according to Mund (2004) and forest soil according to Kolektiv (2007) is completely convincing.

\section{Acknowledgements}

The paper was created thanks to the support provided by Science and Research of the Ministry of Environment project No. Sp-2d3-56-07 - 'Ecological and economic evaluation of forest functions of structurally different forest types'. The terrain survey was carried out within project IGA LDF MENDELU in Brno no. 57/2008 - 'Possible uses of stand ecosystem characteristics synthesis in the management and protection of landscape'.

\section{References}

Adams, J.M. \& Post W.M. (1999). A preliminary estimate of changing calcrete carbon storage on land since the last glacial maximum. Global and Planetary Change, 20, 243-256. DOI: 10.1016/S0921-8181(99)00015-6.

Brown, S. (2002). Measuring carbon in forests: current status and future challenges. Environ. Pollut., 116, 363-372. DOI: 10.1016/S0269-7491(01)00212-3.

Cairns, M.A., Brown, S., Helmer, E.H. \& Baumgardner G.A. (1997). Root biomass allocation in the world's upland 
forests. Oecologia, 111, 1-11. DOI: 10.1007/s004420050201.

Cienciala, E., Černý, M., Apltauer, J. \& Exnerová Z. (2005). Biomass functions applicable to European beech. J. For. Sci., 51, 147-154.

Cienciala, E., Henžlík, V. \& Zatloukal V. (2006). Assessment of carbon stock change in forests - adopting IPPC LULUCF Good Praktice Guidance in the Czech Republic. Lesnicky Časopis, 52(1-2), 17-28.

Claus, A. (2003). FORCAST (Forest Carbon -Nitrogen Trajectories) database.<http://www.dow.wau.nl/natcons/NP/ FORCAST/files_database_forcast2.htm>.

Drápela, K. (2000). Statistics methods II (in Czech). Brno: MZLU.

IPCC (2003). Good practice guidance for land use, land-use change and forestry. Hayama: IPCC/OECD/IEA/IGES. http://www.ipcc-nggip.iges.or.jp.

Jandl, R., Lindner, M., Vesterdal, L., Bauwens, B., Baritz, R., Hagedorn, F., Johnson, D.W., Minkkinen, K. \& Byrne K.A. (2007). How strongly can forest management influence soil carbon sequestration? Geoderma, 137, 253-268. DOI: 10.1016/j.geoderma.2006.09.003.

Joosten, R., Schumacher, J., Wirth, Ch. \& Schulte A. (2004). Evaluating tree karbon predictions for beech (Fagus sylvatica) in western Germany. For. Ecol. Manag., 189, 87-96. DOI: 10.1016/j.foreco.2003.07.037.

Kolektiv (2007). Final report of VaV/640/18/03 CzechCarbo - Study of carbon cycle in terrestrial ecosystems of the Czech Republic.

Korpel, S. (1987). The dynamics of the structure and evolution of natural of beech forests in the Slovak Republic. Acta Facultatis Forestalis, 24, 59-85.

Lal, R. (2005). Forest soil and carbon sequestration. For. Ecol. Manag., 220, 242-258. DOI: 10.1016/j.foreco.2005.08.015.

Mund, M. (2004). Carbon pools of European beech forests (Fagus sylvatica) under different silvicultural management. Dissertation zur Erlangung des Doktorgrades der Fakultät für Forstwissenschaften und Waldökologie der Georg-August-Universität Göttingen.

Muukkonen, P. (2007). Generalized allometric volume and biomass eguations for some tree species in Europe. European Journal of Forest Research, 126, 157-166. DOI: 10.1007/s10342-007-0168-4.

Schneider, J., Urban, J., Rebrošová, K., Douda, P., Dymák, M., Dobrovolný, L. \& Chmelař J. (2008). Possibilities of usage the forest stand ecosystem characteristic synthesis for landscape management (in Czech). Odborná zpráva projektu IGA LDF MZLU č. 57/2008. Brno: LDF MZLU.

Somogyi, Z., Cienciala, E., Mäkipää, R., Muukkonen, P., Lehtonen, A. \& Weiss P. (2007). Indirect methods of largescale forest biomass estimation. European Journal of Forest Research, 126(2), 197-207. DOI: 10.1007/s10342006-0125-7.

Šimek, M. (2003). Basics sciences about soil. 3. Biological processes and cycling of Elements (in Czech). České Budějovice: Jihočeská univerzita.

Tyrrell, M.L. \& Ross J. (2009). Carbon dynamics of temperate forests. In M.L. Tyrell, M.A. Ashton, D. Spalding \& B. Gentry (Eds.), Forests and carbon: a synthesis of science, management, and policy for carbon sequestration in forests (pp. 107-150). Yale School of Forestry \& Environmental Studies.

Vrška, T., Hort, L., Adam, D., Odehnalová, P. \& Horal D. (2002). Dynamics of development the wildwood reservation in the Czech Republic (in Czech). I. Českomoravská vrchovina-Polom, Žákova hora. Praha: Academia.

Vyskot, I., Schneider, J., Pokorný, R. \& Marek M.V. (2011). Carbon sequestration in forest ecosystems within forest function system (in Czech). In M.V. Marek et al. (Eds.), Uhlík v ekosystémech České republiky mènícim se klimatu (pp. 87-206). Praha: Academia.

Vyskot, I. \& Schneider J. (2012). Quantification and evaluation of forest functions (in Czech). In I. Machar \& L. Drobilová (Eds.), Ochrana př́rody a krajiny v České republice - vybrané aktuální problem a možnosti jejich řešení (pp. 250-265). Olomouc: Univerzita Palackého v Olomouci.

Wirth, C., Schulze, E.-D., Schwalbe, G., Tomczyk, S., Weber, G. \& Weller E. (2003). Dynamik der Kohlenstoffvorräte in den Wäldern Thüringens. Abschlussbericht zur 1. Phase des BMBF-Projektes,, Modelluntersuchung zur Umsetzung des Kyoto-Protokolls". Max-Planck Institute for Biogeochemistry.

Wutzler, T., Wirth, Ch. \& Schumacher J. (2008). Generic biomass functions for Common beech (Fagus sylvatica) in Central Europe - predictions and components of uncertainty. Can. J. For. Res., 38(6), 1661-1675. DOI: 10.1139/ X07-194.

Zhang, X., Zhao, Y. \& Ashton M.S. (2009). Methods of measuring carbon in forests. In M.A. Tyrell, M.S. Ashton, D. Spalding \& B. Gentry (Eds.), Forests and carbon: a synthesis of science, management, and policy for carbon sequestration in forests (pp. 183-221). Yale School of Forestry \& Environmental Studies. 